\title{
Charakterystyka drobnych frakcji ziarnowych z przeróbki granitów strzegomskich pod kątem ich zastosowania do produkcji płytek ceramicznych
}

\section{Wprowadzenie}

Szacuje się, że około 55\% światowych zasobów kopalin skaleniowych wykorzystuje się w przemyśle ceramicznym i około $35 \%$ do produkcji szkła. Pozostała ich część jest stosowana głównie jako wypełniacz wyrobów plastikowych i farb (Lewicka 2010). Decydujący wpływ na kształtowanie się ich podaży w skali globalnej ma szczególnie zapotrzebowanie przemysłu ceramicznego. Wśród czynników, które spowodowały gwałtowny wzrost zapotrzebowania na te surowce w ostatniej dekadzie ubiegłego wieku było upowszechnienie techniki szybkiego wypalania płytek ceramicznych (Lewicka 2014). Kluczowe dla poziomu zużycia surowców skaleniowych stało się wprowadzenie na rynek płytek ceramicznych gres porcellanato (kamionka porcelanowa), charakteryzujących się podwyższonymi - w porównaniu z tradycyjnymi płytkami - parametrami fizykomechanicznymi, uzyskanymi dzięki intensywnemu spieczeniu masy ceramicznej w bardzo krótkim czasie. Przejawia się to niską nasiąkliwością produktów $(\leq 0,5 \%)$, przy porowatości otwartej nie

\footnotetext{
* Mgr inż., *** Dr inż., AGH Akademia Górniczo-Hutnicza, Wydział Inżynierii Materiałowej i Ceramiki, Kraków; e-mail:wojpan@agh.edu.pl; mgajek@agh.edu.pl

** Prof. dr hab. inż., Państwowa Wyższa Szkoła Zawodowa w Tarnowie; AGH Akademia Górniczo-Hutnicza, Wydział Inżynierii Materiałowej i Ceramiki, Kraków; e-mail: pwysz@agh.edu.pl
} 
przekraczającej $0,1 \%$. Na przełomie lat osiemdziesiątych i dziewięćdziesiątych ubiegłego wieku proces ich produkcji uległ modyfikacji poprzez wprowadzenie pieców rolkowych, umożliwiających skrócenie czasu wypalania do około 40-60 min (Lewicka i Wyszomirski 2005). Zmianie uległ również skład surowcowy mas ceramicznych, który ukierunkowany był na zmniejszenie ilości kaolinitu kosztem innych, plastycznych surowców ilastych oraz zwiększenie udziału surowców skaleniowych (z około 30\% do nawet 60\%) (Biffi 1997; Cavalcante i in. 2004).

Procesowi wypalania płytek ceramicznych towarzyszą złożone przemiany w składzie mineralnym wyjściowej masy ceramicznej, jak i składu chemicznego powstającej fazy ciekłej (Dondi i in. 2005). Podczas tego procesu kosztem kaolinitu w temperaturze dochodzącej do $1200^{\circ} \mathrm{C}$ tworzy się w znacznej ilości mullit igiełkowy o wybitnie korzystnych właściwościach mechanicznych, który krystalizuje w fazie szklistej pochodzącej ze stopienia skaleni alkalicznych o dużym zwłaszcza udziale $\mathrm{Na}_{2} \mathrm{O}$ (Manfredini i in. 1995). Zachowanie się zestawów surowcowych o charakterze sodowym i potasowym różni się pod względem kinetyki kształtowania się składu fazowego (szybsze w masach sodowych) i lepkości fazy ciekłej (większa w masach potasowych), co znacznie wpływa na końcowe stadium obróbki termicznej. Jest to związane z niższą temperaturą topnienia skalenia sodowego i jego kongruentnym przejściem $\mathrm{w}$ stop $\mathrm{w}$ temperaturze $1118^{\circ} \mathrm{C}$, w odróżnieniu od skalenia potasowego, który rozkłada się inkongruentnie w temperaturze $1150^{\circ} \mathrm{C}$ z utworzeniem leucytu i stopu wzbogaconego w krzemionkę (Wyszomirski i Galos 2007). W związku z tym surowcom skaleniowym stosowanym do produkcji płytek gresowych metodą szybkiego wypalania, oprócz podwyższonej zawartości alkaliów (suma alkaliów min. 7,5\%) stawia się wymagania dotyczące modułu alkaliczności $\mathrm{K}_{2} \mathrm{O}: \mathrm{Na}_{2} \mathrm{O}$, który powinien być mniejszy od 1 (Wójczyk i Partyka 1999). Ponadto w przypadku produktów typu gres porcellanato o jasnym czerepie głównym kryterium jest też niski udział tlenków barwiących $\mathrm{Fe}_{2} \mathrm{O}_{3} \mathrm{i} \mathrm{TiO}_{2}$, który nie powinien przekraczać $0,8 \%$. Tworzywom o barwnym czerepie nie stawia się tak rygorystycznych wymagań odnośnie zawartości tych tlenków.

W Polsce nie rozpoznano dotąd złóż skaleni potasowych i sodowych wybitnie wysokiej czystości. Bazę zasobową kopalin skaleniowych tworzą złoża kopalin skaleniowo-kwarcowych i kwarcowo-skaleniowych zlokalizowanych głównie na Dolnym Śląsku (9 złóż) i w okolicach Krakowa (2 złoża) (Malon 2014). Jak dotąd jako źródło skaleni alkalicznych pozyskiwanych na Dolnym Śląsku wykorzystuje się przede wszystkim takie kopaliny jak: leukogranity ze złoża Strzeblów I, Stary Łom, Pagórki Wschodnie i zubożone w biotyt granity ze złoża Pagórki Zachodnie koło Sobótki, a także drobne frakcje ziarnowe powstające podczas kruszenia granitów strzegomskich głównie z Gniewkowa, Granicznej i Rogoźnicy oraz - do roku 2010 - zwietrzałe, gruboziarniste granity z okolic Jeleniej Góry (Karpniki).

Najszerzej oferowanymi w kraju produktami skaleniowo-kwarcowymi są grysy (o uziarnieniu $0,01-5 ; 0,01-8$ i 5-8 mm), a także mączki szklarskie i ceramiczne $(0,01-0,63$; $0,01-0,71 ; 0,01-0,1 ; 0,01-0,2$ i $0,01-0,5 \mathrm{~mm}$ ) oferowane przez Strzeblowskie Kopalnie Surowców Mineralnych. Są one otrzymywane na drodze prostej przeróbki (kruszenie, prze- 
siewanie, homogenizacja) kopalin eksploatowanych ze złóż: Pagórki Wschodnie, Pagórki Zachodnie, Strzeblów I i Stary Łom. Jakość tych surowców jest stosunkowo niska z uwagi na wysoki udział tlenków barwiących (ponad 0,2\%, max. 0,55\%) (Lewicka 2010). Ważne źródło surowców o wysokiej zawartości alkaliów stanowią również drobne frakcje ziarnowe powstające w procesie produkcji łamanych kruszyw granitowych. Ze względu na niską cenę są one używane w stanie nieprzetworzonym, pomimo stosunkowo wysokiej zawartości $\mathrm{Fe}_{2} \mathrm{O}_{3}$, przez krajowych producentów płytek ceramicznych do wytwarzania wyrobów szkliwionych i płytek gresowych, o ile nie jest wymagana biała barwa czerepu po wypaleniu (Lewicka i Wyszomirski 2005). Proponowane bowiem w krajowej literaturze (m.in. Ciechański i Sokołowski 1995), a nawet wdrożone przez krótki okres czasu pod koniec ubiegłego wieku do praktyki przemysłowej technologie usuwania tlenków barwiących z odpadów granitowych nie znalazły szerszego zastosowania. Autorzy niniejszej pracy dokonali analizy porównawczej drobnych, granitowych frakcji ziarnowych $(0-2 \mathrm{~mm})$ powstających podczas produkcji kruszyw łamanych w kilku kopalniach regionu strzegomskiego, pod kątem ich zastosowania do produkcji płytek ceramicznych bez uprzedniego wzbogacania.

\section{Próbki do badań}

W masywie strzegomskim wyróżnia się kilka odmian granitów, z których najliczniejszą grupę stanowią granity biotytowe. Wśród nich wydziela się typ Kostrzy z odmianami strukturalnymi: równoziarnistą i porfirową oraz typ Chwałkowa (Majerowicz 1972; Walendowski 2012). Granity typu Kostrzy występują w zachodniej części masywu. Są skałami o charakterze monzonitowym, z odmianami porfirowatymi i drobnoziarnistymi z nielicznymi fenokryształami. Odmianę tę reprezentuje frakcja ziarnowa $0-2 \mathrm{~mm}$ pobrana w kopalni w Gniewkowie (próbka 1243). Granity typu Chwałkowa występują we wschodniej części masywu i zawierają mikroklin, plagioklazy, kwarc i biotyt. Materiał poddany badaniu stanowiący tę odmianę został pobrany w kopalniach w Chwałkowie (próbka 1232), Goli Świdnickiej (1234) i Gołaszycach (1236). Odmianą pośrednią między granitami typu Kostrzy i Chwałkowa jest odmiana Granicznej. Występuje ona w północno-wschodnim obrzeżeniu masywu strzegomskiego i kontaktuje się z granitami typu Kostrzy. Są one reprezentowane przez próbki z kopalń w Granicznej (1240) i Strzegomiu (1238).

Do badań przeznaczono reprezentatywne próbki drobnych, odpadowych frakcji granitowych oraz - w przypadku próbek przeznaczonych do wykonania preparatów mikroskopowych - okruchów o wielkości ponad $20 \mathrm{~mm}$, wydzielonych w procesie produkcji kruszywa łamanego. Odpady granitowe charakteryzowały się zmiennym składem granulometrycznym, który w większości stanowiła frakcja ziarnowa $0-2 \mathrm{~mm}$ (ponad $80 \%$ mas.). Wyjątkiem była próbka zwiercin z kopalni w Strzegomiu (1238), która zawierała około $40 \%$ frakcji o uziarnieniu powyżej $2 \mathrm{~mm}$. Zawartość pyłu $(<0,063 \mathrm{~mm})$ w analizowanych próbkach nie przekraczała $5 \%$ mas. 


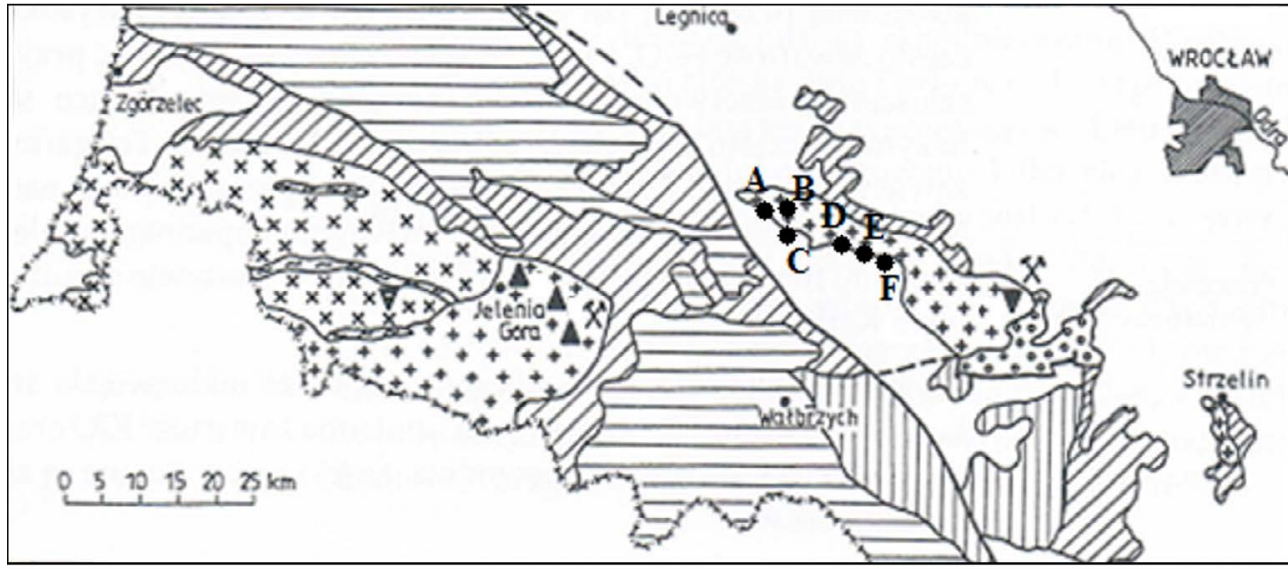

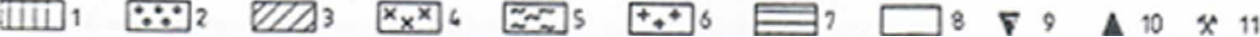

Rys. 1. Rozmieszczenie złóż kopalin skaleniowych na Dolnym Śląsku (Nieć 2005, nieznacznie zmienione) z naniesioną lokalizacją miejsc pobrania próbek (A, B, C, D, E i F)

1 - gnejsy sowiogórskie, 2 - masyw gabrowo-serpentynitowy Ślęży, 3 - utwory metamorficzne Gór

Kaczawskich, Rudaw Janowickich, 4 - gnejsy izerskie, 5 - strefy łupkowe wśród gnejsów izerskich, 6 - granity (masyw karkonoski, strzegomski, strzeliński), 7 - utwory osadowe paleozoiczne i mezozoiczne

w nieckach zewnętrzno- i wewnętrznosudeckiej, 8 - utwory trzeciorzędowe, 9 - udokumentowane złoża leukogranitów, 10 - udokumentowane złoża zwietrzelin granitowych, 11 - złoża eksploatowane,

A - Gniewków, B - Graniczna, C - Strzegom, D - Gołaszyce, E - Gola Świdnicka, F - Chwałków

Fig. 1. Location of feldspar deposits in Lower Silesia (Nieć 2005, with minor changes). Sampling sites are marked as A, B, C, D, E and F

1 - gneisses of the Sowie Mts, 2 - Gabro-serpentinite massif of the Ślęża Mt, 3 - metamorphic rocks of the Kaczawskie Mts and the Rudawy Janowickie Mts, 4 - Izera gneisses, 5 - schists zones within the Izera gneisses, 6 - granites (Karkonosze, Strzegom and Strzelin massifs), 7 -Paleozoic and Mesozoic sedimentary strata in the North-Sudetic Trough and the Inter-Sudetic Trough, 8 - Tertiary strata, 9 - deposits of the leucogranites, for which geological reports have been approved, 10 - deposits of the granite regolith, for which geological reports have been approved, 11 - active quarries.

A - Gniewków, B - Graniczna, C - Strzegom, D - Gołaszyce, E - Gola Świdnicka, F - Chwałków

\section{Metodyka badań}

Pobrane próbki przeznaczono do wykonania następujących badań:

- analiza mikroskopowa w świetle przechodzącym, stosując standardowe preparaty o grubości $0,02 \mathrm{~mm}$, przy użyciu uniwersalnego mikroskopu polaryzacyjnego OLYMPUS BX51 z kamerą BPI2 do wykonania mikrofotografii techniką cyfrową;

- analiza chemiczna przy użyciu metod spektrometrycznych FUS-ICP (fusion-inductively coupled plasma) i TD-ICP (total digestion - inductively coupled plasma), a także metody instrumentalnej neutronowej analizy aktywacyjnej INAA (instrumental neutron activation analysis), wykonana przez Activation Laboratories - ACTLABS w Ancaster (Kanada); 
- analiza w mikroskopie wysokotemperaturowym Misura HSM 3M produkcji włoskiej stosując szybkość ogrzewania próbek o kształcie walca ( $\varnothing=2 \mathrm{~mm}, \mathrm{~h}=3 \mathrm{~mm})$ wynoszącą $10 \mathrm{~K} / \mathrm{min}$;

- oznaczenie parametrów barwy metodą spektrofotometryczną, za pomocą spektrofotometru Konica Minolta CM 700D poprzez określenie współrzędnych w układzie CIE Lab.

Ostatnia z tych analiz została wykonana na sprasowanych i wypalonych pastylkach. Uzyskano je ze sproszkowanego surowca, z którego uformowano walce o średnicy $30 \mathrm{~mm}$ i wysokości około $10 \mathrm{~mm}$ przy użyciu prasy laboratoryjnej pod ciśnieniem około $15 \mathrm{MPa}$. Próbki te następnie wypalono $\mathrm{w}$ piecu laboratoryjnym przetrzymując $\mathrm{w}$ zadanej temperaturze $1200^{\circ} \mathrm{C}$ przez 2 godziny.

\section{Wyniki badań i dyskusja}

\subsection{Analiza składu mineralnego i chemicznego}

Na podstawie mikroskopii polaryzacyjnej stwierdzono, że kopaliny z których pochodzą najdrobniejsze frakcje ziarnowe kruszyw są skałami magmowymi głębinowymi o nieuporządkowanej, masywnej teksturze i średnio-drobnokrystalicznej, równokrystalicznej strukturze. W analizowanych próbkach granitów minerałami głównymi są: występujące w zmiennych ilościach skalenie (reprezentowane przez odmianę alkaliczną i plagioklazy), kwarc i biotyt. We wszystkich przypadkach zawartość tych pierwszych minerałów przekracza $60 \%$, co oszacowano na podstawie oceny wizualnej preparatów. Różnice w składzie mineralnym polegają zazwyczaj na zmiennym stosunku ilościowym skaleni alkalicznych i plagioklazów, zróżnicowanej zawartości kwarcu i biotytu, a także minerałów podrzędnych i akcesorycznych.

Skalenie alkaliczne reprezentowane są zazwyczaj przez pertyt ortoklazowy. Występuje on w formie ksenomorficznych ziaren zawierających liczne wrostki drobnych plagioklazów i kwarcu. W większości próbek ich ziarna osiągają wielkość nawet do $5 \mathrm{~mm}$. Plagioklazy reprezentują odmianę sodową (albit) lub sodowo-wapniowy oligoklaz, który jest w mniejszym lub większym stopniu zserycytyzowany. Minerał ten tworzy hipautomorficzne kryształy wykazujące wielokrotne zbliźniaczenia typu albitowego oraz niekiedy budowę zonalną. Na ogół w preparatach mikroskopowych obserwuje się podobne udziały skalenia sodowego i plagioklazu. Jedynie próbki 1234 i 1236 wykazują wyraźną przewagę ilościową tego drugiego minerału.

Kolejnymi pod względem udziału objętościowego - poza skaleniami - składnikami omawianych skał są kwarc i biotyt. Zawartość tego pierwszego minerału sięga nawet do około 30\% (próbka 1234). Kwarc najczęściej występuje w formie ziaren o nieregularnym kształcie i wielkości do $3 \mathrm{~mm}$, wykazujących zazwyczaj faliste wygaszanie światła. Znacz- 
nie rzadziej spotyka się polikrystaliczne ziarna złożone z kilku drobniejszych osobników (1232, fot. 1) lub ziarna o wielkości $0,1-0,2 \mathrm{~mm}$, przerastające się z podobnej wielkości skaleniami (1243, fot. 2). Z kolei biotyt stanowi do około $15 \%$ objętości próbek. Jego największy udział wykazują skały z Gołaszyc (1236) i Goli Świdnickiej (1234), natomiast najmniejszy - nie przekraczający 3\% objętości - skała z Chwałkowa (1232). Minerał ten występuje w formie hipautomorficznych, blaszkowych kryształów o wielkości do $2 \mathrm{~mm}$, często

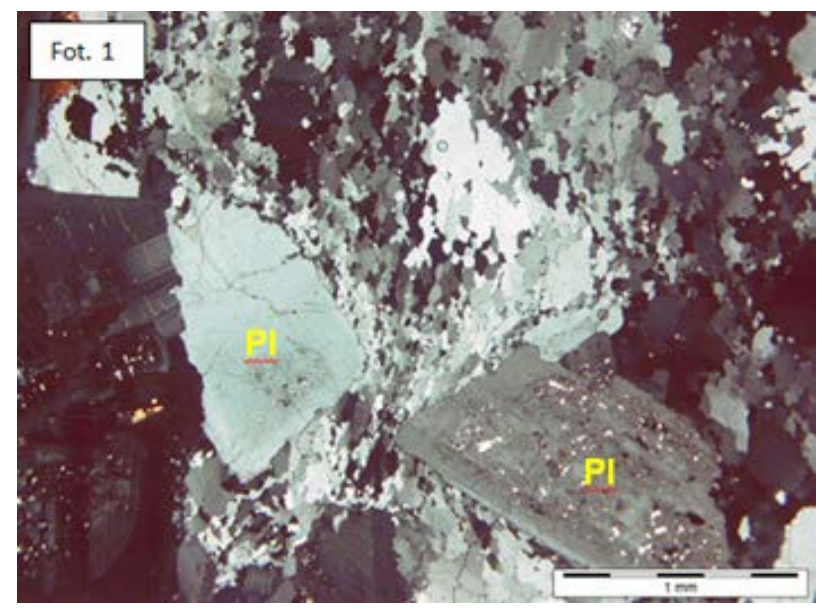

Fot. 1. Polikrystaliczny kwarc złożony z osobników o wydłużonym kształcie pomiędzy ziarnami plagioklazu (Pl). Próbka 1232, mikrofotografia, polaryzatory skrzyżowane

Photo 1. Polycrystalline quartz composed of elongated individuals among plagioclase grains (Pl) Sample 1232, photomicrograph, crossed polarizers

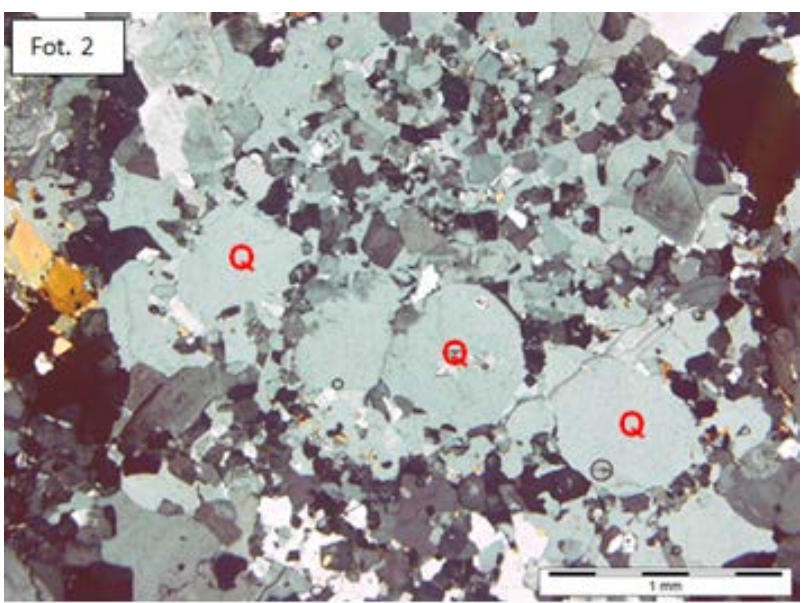

Fot. 2. Przerosty kwarcowo-skaleniowe wokół zaokrąglonych ziaren kwarcu (Q). Próbka 1243, mikrofotografia, polaryzatory skrzyżowane

Photo 2. Quartz-feldspar intergrowths containing ovalized quartz grains (Q). Sample 1243, photomicrograph, crossed polarizers 
o postrzępionych brzegach. Jest w różnym stopniu schlorytyzowany. Proces chlorytyzacji, przebiegający zgodnie z łupliwością biotytu, zaznacza się wyraźną zmianą barwy własnej z brązowej na bladozieloną oraz drastycznym obniżeniem barw interferencyjnych do subnormalnych, niebieskoszarych (fot. 3). Obok prawie niezmienionych kryształów spotyka się całkowite pseudomorfozy chlorytowe po biotycie (fot. 4). Ten ostatni minerał zawiera liczne

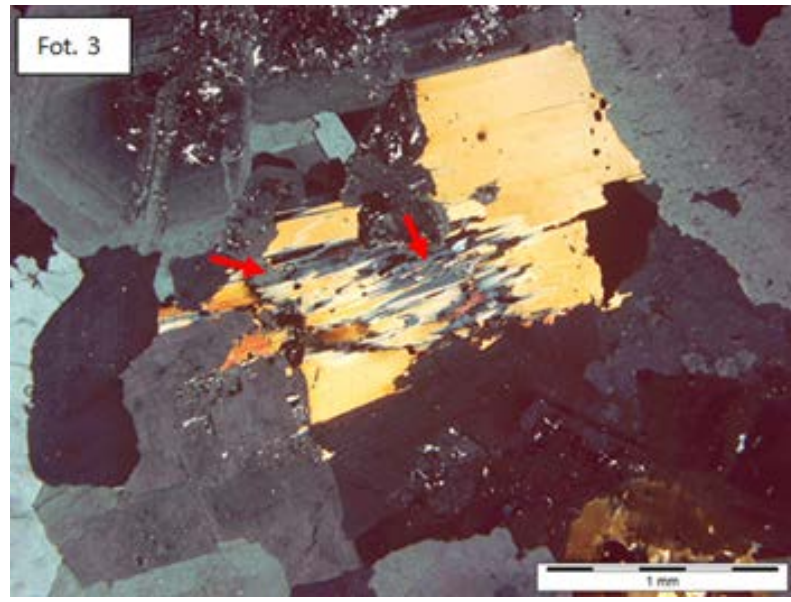

Fot. 3. Blaszka biotytu ze smugami chlorytu o szarych barwach interferencyjnych (strzałki) W lewym, górnym rogu widoczne są łuseczki serycytu wewnątrz kryształów plagioklazu. Próbka 1240, mikrofotografia, polaryzatory skrzyżowane

Photo 3. Biotite flake with streaks of chlorite showing typical grey interference colors (arrows). In the upper left corner small scales of sericite are developed inside plagioclase crystals. Sample 1240, photomicrograph, one polarizer

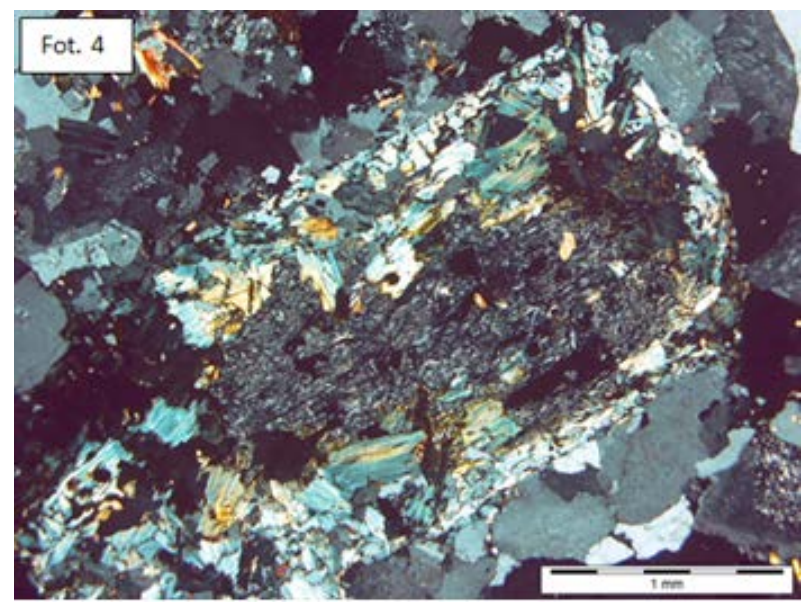

Fot. 4. Pseudomorfoza chlorytowa po minerale maficznym. Wewnątrz widoczne inne, mikrokrystaliczne minerały ilaste. Próbka 1238, mikrofotografia, polaryzatory skrzyżowane

Photo 4. Microcrystalline chlorite pseudomorph developed in an inner part of a mafic mineral. Other clay minerals are also visible. Sample 1238, photomicrograph, crossed polarizers 
zazwyczaj wrostki drobnych kryształów apatytu (fot. 5) i cyrkonu, wokół którego widoczne są często ciemne obwódki - tzw. pola pleochroiczne. Ponadto, minerały podrzędne i akcesoryczne reprezentowane są w badanych próbkach przez wymienione wcześniej minerały, takie jak: serycyt, chloryt pobiotytowy i chloryt pierwotny (próbka 1232, fot. 6) prawdopodobnie pochodzenia hydrotermalnego; a także tytanit (próbka 1234), hematyt (próbki 1236 i 1238) i epidot (1238).

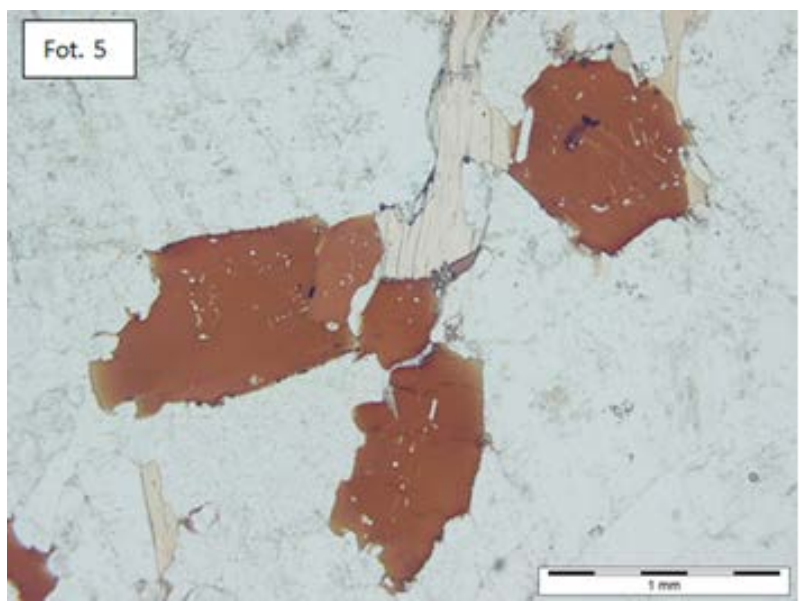

Fot. 5. Blaszki biotytu (brązowe) z widocznymi bezbarwnymi wrostkami apatytu. Próbka 1236, mikrofotografia, jeden polaryzator

Photo 5. Biotite flakes (brown) containing colorless inclusions of apatite. Sample 1236, photomicrograph, one polarizer

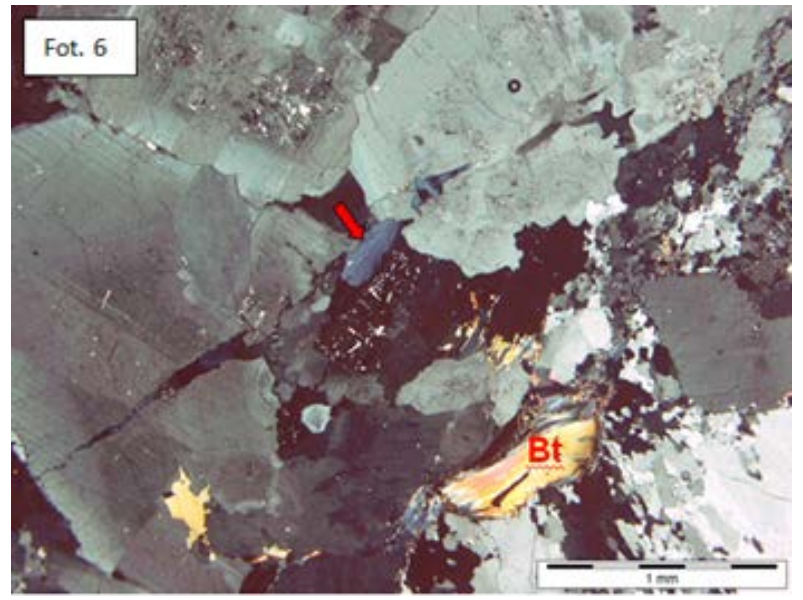

Fot. 6. Odkształcona plastycznie blaszka biotytu (Bt) oraz wachlarzowaty agregat chlorytu pierwotnego (strzałka) pomiędzy kryształami plagioklazów i polikrystalicznego kwarcu. Próbka 1232, mikrofotografia, polaryzatory skrzyżowane

Photo 6. Biotite flake (Bt) revealing plastic deformations, and a fan-shaped grain of primary chlorite (arrow) among the plagioclase crystals and polycrystalline quartz grains. Sample 1232, photomicrograph, crossed polarizers 
Skład chemiczny analizowanych próbek - w odniesieniu do składników głównych (tab. 1) - zdominowany jest przez $\mathrm{SiO}_{2}$, którego obecność wiąże się przede wszystkim z kwarcem oraz ze skaleniami alkalicznymi i plagioklazami. Wysoki udział $\mathrm{Al}_{2} \mathrm{O}_{3}, \mathrm{Na}_{2} \mathrm{O}$ i $\mathrm{K}_{2} \mathrm{O}$ oraz podwyższona zawartość $\mathrm{CaO}$ potwierdzają, że podstawowym składnikiem najdrobniejszych frakcji ziarnowych kruszywa granitowego są skalenie, co zostało potwierdzone w przedstawionej wcześniej analizie mikroskopowej. Wymagana, sumaryczna zawartość alkaliów $\left(\mathrm{Na}_{2} \mathrm{O}+\mathrm{K}_{2} \mathrm{O}\right)$ dla surowców skaleniowych stosowanych do produkcji płytek ceramicznych - która powinna przekraczać min. 7,5\% - została stwierdzona w przypadku próbek z Chwałkowa (próbka 1232), Granicznej (1240) i Gniewkowa (1243). Modułem alkaliczności $\mathrm{K}_{2} \mathrm{O}: \mathrm{Na}_{2} \mathrm{O}<1$ - co jest pożądane w przypadku technologii płytek gresowych charakteryzuje się wyłącznie pierwsza z nich. Zawartość alkaliów w pozostałych próbkach nieznacznie przekracza 7\%, a ich moduł alkaliczności jest mniejszy od 1 dla próbek z Goli Świdnickiej (1234) i Gołaszyc (1236). Warto również zwrócić uwagę na wyraźnie wyższy (ok. 2,5\%) udział $\mathrm{CaO}$ w tych ostatnich próbkach, co świadczy o znacznie bardziej wapniowym charakterze występujących w nich plagioklazów.

Kolejnym, ważnym elementem pod względem technologicznym, jest udział tlenków barwiących, takich jak: $\mathrm{Fe}_{2} \mathrm{O}_{3} \mathrm{i} \mathrm{TiO}_{2}$. Wysoka zawartość (>2\%) tych składników chemicznych w analizowanych surowcach nie stanowi jednak przeszkody do ich wykorzystania do produkcji wyrobów o barwnym czerepie, które są pokrywane szkliwem kryjącym. Za takim kierunkiem wykorzystania przemawia przede wszystkim stosunkowo niski koszt omawianych surowców, który jest znacznie niższy w porównaniu z klasycznymi surowcami skaleniowymi. Według Lewickiej (2013) głównymi nośnikami żelaza i tytanu w badanych przez nią kopalinach skaleniowych ze złóż w rejonie Sobótki są m.in.: schlorytyzowany biotyt z mikrowrostkami rutylu, jasne miki (muskowit, serycyt) będące produktami transformacji

Tabela 1. Składniki główne [\% mas.] frakcji ziarnowych $0-2 \mathrm{~mm}$ otrzymanych podczas produkcji kruszywa łamanego z granitów z Chwałkowa (próbka 1232), Goli Świdnickiej (1234), Gołaszyc (1236), Strzegomia (1238), Granicznej 1240) i Gniewkowa (1243)

Table 1. Major components [wt.\%] of the 0-2 $\mathrm{mm}$ grain fractions obtained in manufacture of the crushed aggregates of granites from Chwałków (sample No. 1232), Gola Świdnicka (1234), Gołaszyce (1236), Strzegom (1238), Graniczna 1240) and Gniewków (1243)

\begin{tabular}{|c|c|c|c|c|c|c|c|c|c|c|c|c|}
\hline Próbka & $\mathrm{SiO}_{2}$ & $\mathrm{Al}_{2} \mathrm{O}_{3}$ & $\mathrm{Fe}_{2} \mathrm{O}_{3}$ & $\mathrm{TiO}_{2}$ & $\mathrm{CaO}$ & $\mathrm{MgO}$ & $\mathrm{MnO}$ & $\mathrm{Na}_{2} \mathrm{O}$ & $\mathrm{K}_{2} \mathrm{O}$ & $\mathrm{P}_{2} \mathrm{O}_{5}$ & $\begin{array}{c}\text { Strata } \\
\text { prażenia }\end{array}$ & Suma \\
\hline 1232 & 70,60 & 14,93 & 1,96 & 0,27 & 1,39 & 0,51 & 0,05 & 4,09 & 3,60 & 0,09 & 1,27 & 98,76 \\
\hline 1234 & 69,08 & 14,56 & 2,57 & 0,43 & 2,48 & 0,83 & 0,05 & 3,85 & 3,46 & 0,14 & 1,08 & 98,54 \\
\hline 1236 & 70,51 & 15,20 & 2,76 & 0,45 & 2,41 & 0,94 & 0,06 & 3,74 & 3,27 & 0,14 & 0,73 & 100,20 \\
\hline 1238 & 72,08 & 13,28 & 2,48 & 0,28 & 1,01 & 0,26 & 0,05 & 3,00 & 4,41 & 0,07 & 1,89 & 100,20 \\
\hline 1240 & 74,98 & 13,12 & 2,02 & 0,26 & 1,63 & 0,42 & 0,05 & 3,19 & 4,35 & 0,09 & 0,44 & 100,50 \\
\hline 1243 & 70,95 & 13,74 & 2,72 & 0,31 & 1,29 & 0,35 & 0,05 & 3,28 & 4,75 & 0,10 & 0,99 & 98,70 \\
\hline
\end{tabular}


biotytu oraz minerały ciężkie. Oprócz tego żelazo może występować w samych skaleniach, w których strukturze jony $\mathrm{Fe}^{3+}$ niekiedy diadochowo podstawiają glin.

Innymi jonami, których śladowa nawet ilość w znacznym stopniu wpływa na barwę tworzywa ceramicznego po wypaleniu są w szczególności jony metali przejściowych, takie jak: $\mathrm{V}^{3+}, \mathrm{Cr}^{3+}, \mathrm{Cr}^{6+}, \mathrm{Mn}^{2+}, \mathrm{Co}^{2+}, \mathrm{Ni}^{2+}$ i Cu${ }^{2+}$ (Sikora 1974). Wykazują one bowiem zdolność selektywnej absorpcji światła widzialnego. Z pierwiastków śladowych w omawianych próbkach drobnoziarnistych frakcji granitowych obserwuje się podwyższoną zawartość przede wszystkim wanadu (do 43 ppm), chromu (do 39 ppm) i miedzi (do 18 ppm) (tab. 2). W przypadku dwóch pierwszych pierwiastków uwidacznia się wyraźnie zwiększony ich udział w próbkach 1232, 1234 i 1236, które charakteryzują się przewagą plagioklazów nad skaleniami alkalicznymi.

Tabela 2. Pierwiastki śladowe [ppm] we frakcjach ziarnowych $0-2 \mathrm{~mm}$ otrzymanych podczas produkcji kruszyw łamanych z granitów z Chwałkowa (próbka 1232), Goli Świdnickiej (1234), Gołaszyc (1236), Strzegomia (1238), Granicznej 1240) i Gniewkowa (1243)

Table 2. Trace elements [ppm] of the 0-2 $\mathrm{mm}$ grain fractions obtained in manufacture of the crushed aggregates of granites from Chwałków (sample No. 1232), Gola Świdnicka (1234), Gołaszyce (1236), Strzegom (1238), Graniczna 1240) and Gniewków (1243)

\begin{tabular}{|c|c|c|c|c|c|c|c|c|}
\hline \multirow{2}{*}{ Składnik } & \multirow{2}{*}{$\begin{array}{c}\text { Liczba } \\
\text { atomowa }\end{array}$} & \multicolumn{9}{|c|}{ Próbka } \\
\cline { 3 - 9 } & próg detekcji & 1232 & 1234 & 1236 & 1238 & 1240 & 1243 \\
\hline $\mathrm{Be}$ & 4 & 1 & 3 & 3 & 3 & 4 & 3 & 4 \\
\hline $\mathrm{S}[\%]$ & 16 & 0,001 & 0,061 & 0,027 & 0,022 & 0,015 & 0,016 & 0,033 \\
\hline $\mathrm{Sc}$ & 21 & 0,1 & 4,7 & 5,6 & 6,2 & 4,6 & 4,3 & 5,9 \\
\hline $\mathrm{V}$ & 23 & 5 & 20 & 41 & 43 & 16 & 22 & 19 \\
\hline $\mathrm{Cr}$ & 24 & 1 & 17 & 25 & 39 & 12 & 11 & 24 \\
\hline $\mathrm{Co}$ & 27 & 1 & 4 & 7 & 8 & 4 & $<1$ & 6 \\
\hline $\mathrm{Ni}$ & 28 & 1 & 6 & 7 & 11 & 6 & 7 & 6 \\
\hline $\mathrm{Cu}$ & 29 & 1 & 13 & 12 & 18 & 10 & 14 & 18 \\
\hline $\mathrm{Zn}$ & 30 & 1 & 57 & 49 & 54 & 74 & 46 & 63 \\
\hline $\mathrm{As}$ & 33 & 2 & $<2$ & $<2$ & $<2$ & 6 & $<2$ & 2 \\
\hline $\mathrm{Se}$ & 34 & 3 & $<3$ & $<3$ & $<3$ & $<3$ & $<3$ & $<3$ \\
\hline $\mathrm{Br}$ & 35 & 1 & $<1$ & $<1$ & $<1$ & $<1$ & $<1$ & $<1$ \\
\hline $\mathrm{Rb}$ & 37 & 20 & 130 & 150 & 140 & 230 & 200 & 270 \\
\hline $\mathrm{Sr}$ & 38 & 2 & 228 & 340 & 343 & 73 & 133 & 100 \\
\hline $\mathrm{Y}$ & 39 & 1 & 20 & 16 & 17 & 30 & 26 & 34 \\
\hline $\mathrm{Zr}$ & 40 & 2 & 97 & 126 & 144 & 199 & 154 & 215 \\
\hline
\end{tabular}


Tabela 2. cd.

Table 2. cont.

\begin{tabular}{|c|c|c|c|c|c|c|c|c|}
\hline \multirow{2}{*}{ Składnik } & \multirow{2}{*}{$\begin{array}{c}\text { Liczba } \\
\text { atomowa }\end{array}$} & \multicolumn{7}{|c|}{ Próbka } \\
\hline & & próg detekcji & 1232 & 1234 & 1236 & 1238 & 1240 & 1243 \\
\hline Mo & 42 & 2 & $<2$ & $<2$ & $<2$ & $<2$ & $<2$ & $<2$ \\
\hline $\mathrm{Ag}$ & 47 & 0,5 & $<0,5$ & $<0,5$ & $<0,5$ & $<0,5$ & $<0,5$ & $<0,5$ \\
\hline Cs & 55 & 0,5 & $<0,5$ & $<0,5$ & 2,9 & 8,8 & 5,1 & 7,9 \\
\hline $\mathrm{Ba}$ & 56 & 3 & 693 & 750 & 736 & 454 & 504 & 679 \\
\hline $\mathrm{La}$ & 57 & 0,2 & 22,9 & 30,6 & 25,9 & 45,1 & 43,3 & 52,7 \\
\hline $\mathrm{Ce}$ & 58 & 3 & 41 & 52 & 47 & 86 & 80 & 99 \\
\hline $\mathrm{Nd}$ & 60 & 5 & 11 & 20 & 20 & 32 & 25 & 40 \\
\hline $\mathrm{Sm}$ & 62 & 0,1 & 3,1 & 3,6 & 3,6 & 5,8 & 5,2 & 6,7 \\
\hline $\mathrm{Eu}$ & 63 & 0,1 & 0,5 & 0,8 & 0,5 & 0,9 & 0,9 & 0,9 \\
\hline $\mathrm{Tb}$ & 65 & 0,5 & $<0,5$ & $<0,5$ & $<0,5$ & $<0,5$ & $<0,5$ & $<0,5$ \\
\hline $\mathrm{Yb}$ & 70 & 0,1 & 2,1 & 1,3 & 2,2 & 3,6 & 2,2 & 3,7 \\
\hline $\mathrm{Lu}$ & 71 & 0,05 & 0,40 & 0,11 & 0,33 & 0,72 & 0,38 & 0,55 \\
\hline $\mathrm{Hf}$ & 72 & 0,5 & 2,6 & 3,0 & 3,3 & 5,2 & 3,6 & 5,8 \\
\hline $\mathrm{Ta}$ & 73 & 1 & $<1$ & $<1$ & $<1$ & $<1$ & $<1$ & 2 \\
\hline W & 74 & 3 & $<3$ & $<3$ & $<3$ & $<3$ & $<3$ & $<3$ \\
\hline Ir [ppb] & 77 & 5 & $<5$ & $<5$ & $<5$ & $<5$ & $<5$ & $<5$ \\
\hline $\mathrm{Au}[\mathrm{ppb}]$ & 79 & 5 & $<5$ & $<5$ & $<5$ & $<5$ & $<5$ & $<5$ \\
\hline $\mathrm{Hg}$ & 80 & 1 & $<1$ & $<1$ & $<1$ & 1 & $<1$ & $<1$ \\
\hline $\mathrm{Pb}$ & 82 & 5 & 19 & 15 & 18 & 35 & 23 & 22 \\
\hline $\mathrm{Bi}$ & 83 & 2 & $<2$ & $<2$ & $<2$ & $<2$ & $<2$ & $<2$ \\
\hline
\end{tabular}

W odniesieniu do pozostałych pierwiastków śladowych uwidacznia się szczególnie wysoki udział baru (dochodzący do 750 ppm), strontu (do 343 ppm), rubidu (do 270 ppm) i cyrkonu (do 215 ppm). Zawartość dwóch pierwszych pierwiastków związana jest z podstawieniami izomorficznymi w strukturze plagioklazu w miejsce wapnia. Stąd znacznie większy ich udział obserwuje się w próbkach 1232, 1234 i 1236, które są bardziej zasobne w ten minerał. Z kolei rubid występuje w większej ilości pozostałych próbek, które charakteryzuje większy udział skaleni alkalicznych (ortoklaz). Przyczyną są podstawienia izomorficzne rubidu w miejsce potasu w strukturze tego minerału. Podwyższona zaś zawartość cyrkonu Zr wiąże się z obecnością typowego dla granitów minerału pobocznego, jakim jest cyrkon $\mathrm{Zr}\left[\mathrm{SiO}_{4}\right]$. 
Warto odnotować również znaczący udział w analizowanych próbkach lekkich pierwiastków ziem rzadkich, takich jak cer (do 99 ppm), lantan (do ok. 53 ppm) i neodym (do 40 ppm). Zawartość powyższych pierwiastków jest związana głównie z biotytem i w mniejszym stopniu ze skaleniami alkalicznymi i kwaśnymi plagioklazami (Polański 1988).

\subsection{Ocena właściwości technologicznych}

Charakterystyczne cechy termiczne drobnoziarnistych frakcji granitowych wyznaczono przy użyciu mikroskopu wysokotemperaturowego. Badania te polegają na obserwacji i fotograficznej rejestracji zmian konturów próbki zachodzących wraz ze wzrostem temperatury, co umożliwia określenie temperatur charakterystycznych, takich jak:

- temperatura spiekania $T_{S}$ - temperatura w której próbka osiąga 98\% wysokości początkowej;

- temperatura mięknięcia $T_{M}$ - określana również jako początek topnienia (Dumitrache i Teoreanu 2006), w której próbka wykazuje wyraźne zaokrąglenie krawędzi;

- temperatura kuli $T_{K}-$ wysokość próbki równa jest średnicy;

- temperatura półkuli $T_{P}-$ wysokość próbki jest równa połowie średnicy, określa ona koniec jej topnienia;

- temperatura rozpływu $T_{R}$ - wysokość próbki równa jest 1/3 wysokości początkowej.

Pomiary w mikroskopie wysokotemperaturowym pozwoliły na ustalenie dla analizowanych surowców powyższych temperatur z wyłączeniem temperatury rozpływu i - w przypadku próbek 1234, 1236, 1238 - temperatury półkuli. Rozwiązanie konstrukcyjne mikroskopu uniemożliwia bowiem rejestrację obrazu w zbyt wysokich temperaturach i powoduje jego wyłączenie, co zapobiega uszkodzeniu stolika pomiarowego cieczą powstającą z topiącej się próbki.

Temperatury charakterystyczne analizowanych surowców zostały przedstawione na rysunku 2. W szczególności temperatura kuli - wyznaczona dla wszystkich analizowanych próbek - wkazuje na znaczące różnice w przebiegu procesu termicznego. Próbki charakteryzujące się modułem alkaliczności mniejszym od $1(1232,1234,1236)$ wykazują znacznie niższe wartości temperatury kuli - mieszczące się w zakresie $1339-1395^{\circ} \mathrm{C}$ - aniżeli próbki o większej zawartości skalenia potasowego w porównaniu ze skaleniem sodowym. Warto zwrócić także uwagę na najniższą wielkość tego parametru dla próbek z Goli Świdnickiej (1234) i Gołaszyc (1236). Spowodowane jest to m.in. podwyższoną w nich zawartością żelaza. W przypadku pozostałych temperatur charakterystycznych tak wyraźnych różnic nie zaobserwowano.

Kolejnym, ważnym parametrem w technologii płytek gresowych jest barwa ich czerepu po wypaleniu. Za nią, w największym stopniu - w porównaniu z innymi składnikami masy ceramicznej - odpowiedzialna jest zawartość niektórych pierwiastków głównych i śladowych, omawianych w rozdziale 3.1 niniejszej pracy. Pomiary barwy wykonano na pastylkach uformowanych z badanych frakcji granitowych po ich uprzednim zmieleniu, które 


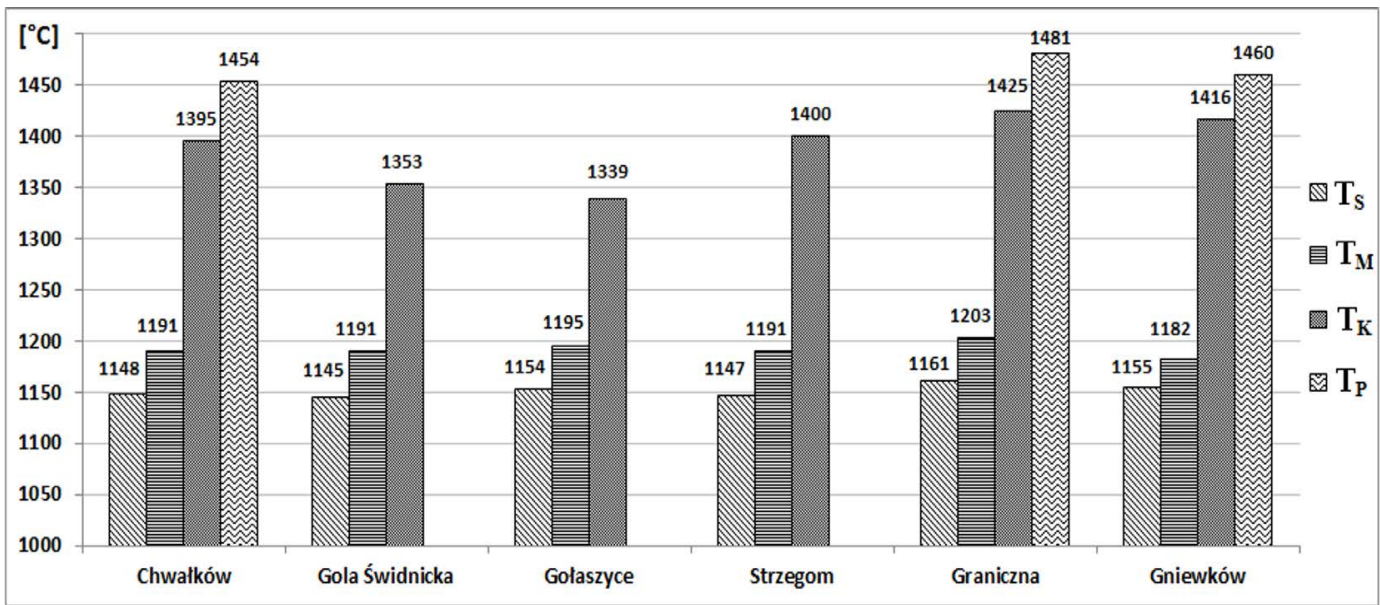

Rys. 2. Temperatury charakterystyczne - wyznaczone przy użyciu mikroskopu wysokotemperaturowego próbek uprzednio zmielonych i sprasowanych, drobnych frakcji ziarnowych $(0-2 \mathrm{~mm})$ granitów z Chwałkowa (próbka 1232), Goli Świdnickiej (1234), Gołaszyc (1236), Strzegomia (1238), Granicznej (1240) i Gniewkowa (1243)

Fig. 2. Characteristic temperatures, determined with a hot stage microscope, of the ground and pelletizated samples prepared from fine-grained fractions $(0-2 \mathrm{~mm}$ ) of the granites from Chwałków (sample No. 1232), Gola Świdnicka (1234), Gołaszyce (1236), Strzegom (1238), Graniczna 1240) and Gniewków (1243)

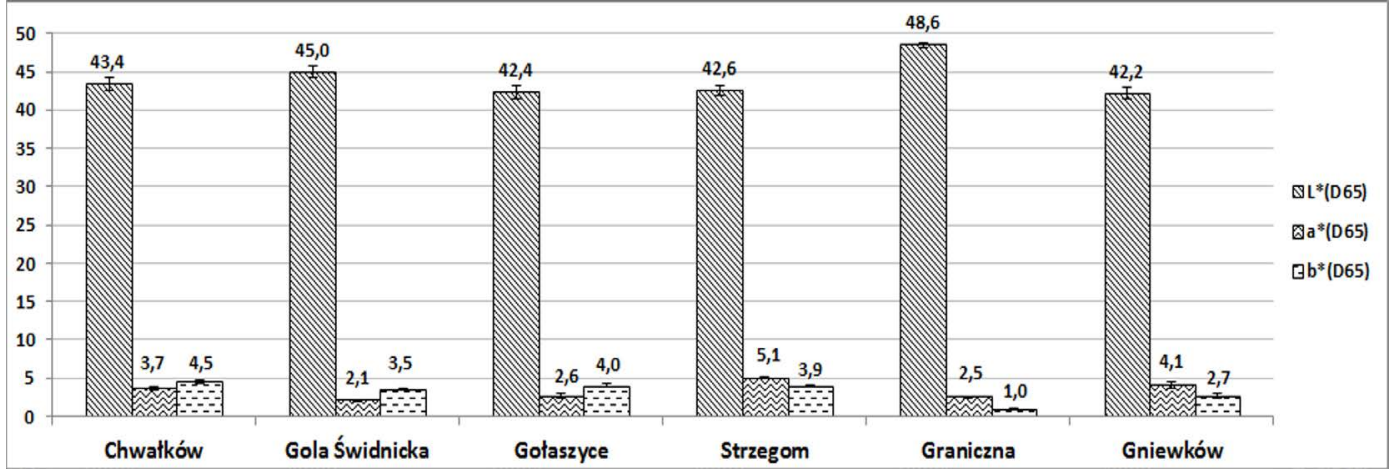

Rys. 3. Parametry barwy L*, $\mathrm{a}^{*}, \mathrm{~b}^{*}$ wypalonych $\left(1200^{\circ} \mathrm{C}\right)$ próbek uprzednio zmielonych

i sprasowanych frakcji ziarnowych (0-2 $\mathrm{mm}$ ) otrzymanych podczas produkcji kruszyw łamanych z granitów z Chwałkowa (próbka 1232), Goli Świdnickiej (1234), Gołaszyc (1236), Strzegomia (1238), Granicznej (1240) i Gniewkowa (1243)

Fig. 3. Parameters of color: $\mathrm{L}^{*}, \mathrm{a}^{*}$ and $\mathrm{b}^{*}$, of the samples prepared by grounding and pelletization the fine-grained fractions $(0-2 \mathrm{~mm})$ of the granites from Chwałków (sample No. 1232), Gola Świdnicka (1234), Gołaszyce (1236), Strzegom (1238), Graniczna 1240) and Gniewków (1243), and then fired at $1200^{\circ} \mathrm{C}$ 
wypalono w temperaturze $1200^{\circ} \mathrm{C}$. Do tego celu wykorzystano najczęściej stosowany systemem diagnostyki barw, tj. model CIE Lab, który opiera się na kolorach przeciwstawnych. Wartość $L$ odnosi się do jasności próbki i mieści się w przedziale od 0 (czerń absolutna) do 100 (idealna biel), wartość $a$ odpowiada barwie czerwonej $(a>0)$ lub zielonej $(a<0)$, zaś wartość $b$ - barwie żółtej $(b>0)$ lub niebieskiej $(b<0)$ (Mielicki 1997).

Wszystkie $\mathrm{z}$ analizowanych próbek charakteryzują się stosunkowo ciemną barwą po wypaleniu. Trzy z nich (próbki 1234, 1236 i 1240) wykazują barwę szarą, pozostałe zaś czerwono-brunatną. Spowodowane jest to przede wszystkim znaczną zawartością $\mathrm{Fe}_{2} \mathrm{O}_{3}$ w próbkach, która wpływa na niską jasność - reprezentowaną przez $L$ - i dodatnią wartość $a$ (rys. 3). Nie zaobserwowano jednak ścisłej zależności pomiędzy zawartością tego tlenku a wspomnianymi parametrami. Przyczyną może być zróżnicowany w badanych próbkach stosunek $\mathrm{Fe}^{2+} / \mathrm{Fe}^{3+}$ w powstałych w wysokiej temperaturze fazach krystalicznych. Wielkość tego stosunku wpływa na pojawienie się całej gamy barw od żółtej po zieloną. Ponadto końcowa barwa wypalonych próbek zależy też od zawartości innych - poza żelazem - pierwiastków chemicznych, takich jak: tytan, mangan, pierwiastki ziem rzadkich, ołów, tor i uran (m.in. Lewicka 2015). Omówienie zależności pomiędzy barwą a udziałem tych składników jest jednak obszernym, skomplikowanym zagadnieniem i wykracza poza zakres niniejszej pracy.

\section{Podsumowanie i wnioski}

Przedmiotem badań były próbki drobnych frakcji ziarnowych $0-2 \mathrm{~mm}$ pochodzących z procesu produkcji kruszyw łamanych w kopalniach granitu w Chwałkowie (próbka 1232), Goli Świdnickiej (1234), Gołaszyc (1236), Strzegomiu (1238), Granicznej (1240) i Gniewkowie (1243). Ich głównymi minerałami są skalenie (zarówno alkaliczne jak i kwaśne plagioklazy), kwarc i biotyt. Zawartość pierwszych z nich przekracza zazwyczaj $60 \%$ składu mineralnego próbek. Na podstawie analizy chemicznej wykazano, że udział alkaliów $\left(\mathrm{Na}_{2} \mathrm{O}+\mathrm{K}_{2} \mathrm{O}\right)$ w próbkach 1232, 1240 i 1243 jest większy od 7,5\%, co pozwala na zakwalifikowanie ich jako topników do produkcji płytek ceramicznych o barwnym czerepie. Ponadto próbka z Chwałkowa (1232) charakteryzuje się korzystnym w aspekcie tego zastosowania modułem alkaliczności $\left(\mathrm{K}_{2} \mathrm{O}: \mathrm{Na}_{2} \mathrm{O}\right)$ mniejszym od 1 .

Właściwości technologiczne określone na podstawie badań metodą mikroskopu wysokotemperaturowego wskazują, że najniższą temperaturą kuli (która mówi o znacznym udziale fazy ciekłej podczas obróbki termicznej) rzędu $1340-1350^{\circ} \mathrm{C}$ charakteryzują się próbki z Goli Świdnickiej (1232) i Gołaszyc (1236). Uzasadniać to może podwyższona w nich zawartość $\mathrm{Fe}_{2} \mathrm{O}_{3}$, który wchodząc w reakcje w wysokich temperaturach w fazie stałej z innymi składnikami mineralnymi tworzy niskotopliwe fazy krystaliczne. Najwyższy udział $\mathrm{Na}_{2} \mathrm{O}$ i najniższa, w porównaniu z pozostałymi próbkami zawartość $\mathrm{Fe}_{2} \mathrm{O}_{3}$ w badanym materiale z Chwałkowa (1232) sugeruje najlepsze jego parametry w aspekcie produkcji płytek ceramicznych o barwnym czerepie. 
Podziękowania

Autorzy dziękuja Panu dr. Tadeuszowi Szydłakowi (AGH) za pomoc w opisie mikroskopowym badanych granitów.

Niniejsza praca została wykonana w ramach badań własnych Wydziału Inżynierii Materiałowej $i$ Ceramiki AGH w Krakowie (umowa nr 15.11.160.618).

\section{LITERATURA}

Biffi, G. 1997. Gres Porcellanato manuale di fabbricazione e tecniche di impiego. Gruppo editiorale Faenza editrice S.p.A.

Cavalcante i in. 2004 - Cavalcante, P.M.T., Dondi, M., Ercolani, G., Guarini, G., Melandri, C., Raimondo, M. i Rocha e Almendra, E. 2004. The influence of microstructure on the performance of white porcelain stoneware. Ceramics International 30, s. 953-963.

Ciechański, S. i Sokołowski, M. 1995. Możliwości i warunki zagospodarowania odpadów z eksploatacji i przeróbki surowców skalnych. Mat. Konf. Problemy zagospodarowania odpadów mineralnych, Wisła, s. 91-106.

Dumitrache, R.L. i Teoreanu, I. 2006. Melting behaviour of feldspar porcelain glazes. U.P.B. Sci. Bull., Series B, $46,1, \mathrm{~s}, 3-16$.

Dondi i in. 2005 - Dondi, M., Ercolani, G., Guarini, G., Melandri, C., Raimondo, M., Rocha e Almenda E. i Cavalcante. P.M.T. 2005. The role of surface microstructure on the resistance to stains of porcelain stoneware tiles. Journal of the European Ceramic Society 25, 4, s. 357-365.

Henderson, P. 1984. Rare Earth Element Geochemistry. Elsevier, New York

Lewicka, E. 2010. Conditions of the feldspathic raw materials supply from domestic and foreign sources in Poland. Gospodarka Surowcami Mineralnymi-Mineral Resources Management 26 (4), s. 5-19.

Lewicka, E. 2013. Barwa po wypaleniu a skład mineralny kopalin skaleniowych z rejonu Sobótki. Gospodarka Surowcami Mineralnymi - Mineral Resources Management 29 (1), s. 35-51.

Lewicka, E. 2014. Skalenie i Surowce Skaleniowe [W:] Smakowski T., Ney R., Galos K. red. Bilans Gospodarki Surowcami Mineralnymi Polski i Świata 2012. Wyd. IGSMiE PAN, Kraków, s. 803-816.

Lewicka, E. 2015. Badanie wpływu domieszek żelaza na parametry barwy kopalin skaleniowo-kwarcowych po wypaleniu. Gospodarka Surowcami Mineralnymi - Mineral Resources Management 31, 1, s. 81-94.

Lewicka, E. i Wyszomirski, P. 2005. Czy istnieją możliwości powiększenia bazy zasobowej surowców skaleniowych dla przemysłu ceramicznego w Polsce? Gospodarka Surowcami Mineralnymi - Mineral Resources Management 21 (s. 1), s. 135-147.

Majerowicz, A. 1972. Masyw granitowy Strzegom-Sobótka. Geologia Sudetica, VI, s. 7-88.

Malon A., 2014. Surowce Skaleniowe [W:] Szuflicki M., Malon A., Tymiński M. red. Bilans Zasobów Złóż Kopalin w Polsce 2014. PIG-PIB, Warszawa 2014.

Manfredini I in. 1995 - Manfredini, T., Pellacini, G.L., Romagnoli, M. i Pennisi, L. 1995. Porcelanized Stoneware Tile. Amer. Cer. Soc. Bull. 74, 5, s. 76-79

Mielicki, J. 1997. Zarys wiadomości o barwie. Fundacja Rozwoju Polskiej Kolorystyki, Łódź.

Nieć, R. 2005. Złoża kopalin skaleniowych [W:] Monografia Surowce Mineralne Polski. R. Ney red. Tom Surowce skalne - Surowce krzemionkowe i skaleniowe. Wyd. IGSMiE PAN, Kraków, s. 101-122.

Polański, A. 1988. Podstawy Geochemii. Wyd. Geol. Warszawa.

Sikora, W. 1974. Żelazo w kaolinach pierwotnych Dolnego Śląska. Prace Mineralogiczne 39. Warszawa: Wyd. Geologiczne, $76 \mathrm{~s}$.

Walendowski, H. 2012. Granity strzegomskie. Nowy Kamieniarz 58, 1, s. 56-57.

Wójczyk, M. i Partyka, J. 1999. Produkcja gresu porcellanato. Wokół Ptytek Ceramicznych 4, s. 30-31. Wyd. SIGMA-NOT Warszawa.

Wyszomirski, P. i Galos, K. 2007. Surowce mineralne i chemiczne przemystu ceramicznego. Wyd. AGH, Kraków. 


\section{CHARAKTERYSTYKA DROBNYCH FRAKCJI ZIARNOWYCH \\ Z PRZERÓBKI GRANITÓW STRZEGOMSKICH POD KĄTEM ICH ZASTOSOWANIA DO PRODUKCJI PLYTEK CERAMICZNYCH}

Słowa kluczowe

drobne frakcje granitowe, granity strzegomskie, topniki ceramiczne, płytki gresowe

\section{Streszczenie}

W celu zagospodarowania drobnych, odpadowych frakcji granitowych $(0-2 \mathrm{~mm})$ powstających podczas produkcji kruszywa łamanego przeprowadzono badania ich przydatności jako surowca skaleniowego (topniki) dla celów przemysłu ceramicznego. Przedmiotem badań były próbki pochodzące z sześciu kopalń zlokalizowanych w masywie granitoidowym Strzegom-Sobótka (Dolny Śląsk). Charakterystykę surowcową przeprowadzono metodą mikroskopową i na podstawie badań chemicznych. Przydatność tych surowców do produkcji płytek ceramicznych określono opierając się na mikroskopii wysokotemperaturowej oraz spektrofotometrycznym pomiarze barwy próbek po wypaleniu w $1200^{\circ} \mathrm{C}$. Na ich podstawie stwierdzono, że w szczególności drobna frakcja ziarnowa granitu z Chwałkowa może stanowić wartościowy surowiec skaleniowy do produkcji płytek gresowych. Charakteryzuje się ona m.in. zawartością alkaliów przekraczającą 7,5\% oraz modułem alkaliczności $\left(\mathrm{K}_{2} \mathrm{O}: \mathrm{Na}_{2} \mathrm{O}\right)$ mniejszym od 1 , co w znaczącym stopniu wpływa na obniżenie temperatury topnienia i pojawienie się - w przeciwieństwie do surowca z przewagą skaleni potasowych nad plagioklazami w niższej temperaturze odpowiedniej ilości fazy ciekłej. Surowiec ten może być - podobnie jak i inne drobne frakcje granitowe - wykorzystywany jako substytut tradycyjnych surowców skaleniowych m.in. do produkcji płytek gresowych o barwnym czerepie.

\section{CHARACTERISTICS OF THE FINE-GRAINED FRACTIONS} OF THE CRUSHED STRZEGOM GRANITES AS POSSIBLE MATERIALS IN MANUFACTURE OF CERAMIC TILES

Key words

fine-grained granite waste, Strzegom granites, ceramic fluxes, gres tiles

\section{Abstract}

Fine-grained fractions ( $0-2 \mathrm{~mm})$, representing waste in the manufacture of crushed road aggregates of some granites, were tested as possible feldspar raw materials that could be utilized as a flux by the ceramics industry. Samples were collected in six quarries located within the Strzegom-Sobótka (Lower Silesia) granitoid massif. The industrial properties of the granite fines were established using the microscopic method and chemical analyses, while the tests of their suitability to produce ceramic tiles were carried out via hot stage microscopy and spectrophotometric color measurements of the tiles fired at $1200^{\circ} \mathrm{C}$. The results indicate that it is the fine-grained waste of the Chwałków granite that may 
be a valuable feldspar-bearing raw material to manufacture gres tiles. It is characterized by, among other indicators, the total alkali content exceeding $7.5 \%$ and the alkalinity modulus $\left(\mathrm{K}_{2} \mathrm{O}: \mathrm{Na}_{2} \mathrm{O}\right)$ being below 1 . These parameters significantly lower the melting temperature and even at such conditions result in the formation of sufficient volumes of a liquid phase, contrary to the mineral raw materials in which K-feldspars prevail over plagioclases. This waste material and other fine-grained fractions tested may, therefore, be a substitute for the traditional feldspar-bearing raw materials that are utilized in the manufacture of gres tiles with coloured bodies, among other usages. 
